DOI: https://doi.org/10.47405/mjssh.v6i9.986

\begin{tabular}{|c|c|}
\hline 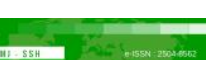 & Malaysian Journal of Social Sciences and Humanities (MJSSH) \\
\hline Malaysian Journal of & Volume 6, Issue 9, September 2021 \\
\hline (MJ-SSH) & e-ISSN : 2504-8562 \\
\hline & $\begin{array}{l}\text { Journal home page: } \\
\text { www.msocialsciences.com }\end{array}$ \\
\hline
\end{tabular}

\title{
Forecasting Natural Rubber Price in Malaysia by 2030
}

\author{
Nor Farah Hanim Binti Mohamad Norizan ${ }^{1,3}$, Zahayu Binti Md Yusof 1,2 \\ ${ }^{1}$ School of Quantitative Sciences, Universiti Utara Malaysia, 06010 UUM Sintok Kedah Malaysia \\ 2Institute of Strategic Industrial Decision Modelling, School of Quantitative Sciences, Universiti Utara Malaysia, 06010 \\ UUM Sintok Kedah Malaysia \\ ${ }^{3}$ NFH Tanjung Mutiara, Kampung Tanjung Mukim Padang Terap Kiri, 06300 Kuala Nerang Kedah
}

Correspondence: Nor Farah Hanim Binti Mohamad Norizan (farniem176@gmail.com)

\begin{abstract}
Natural rubber (NR) has recently become one of Malaysia's most important economic sectors. Despite, the price of Standard Malaysia Rubber 20 changes frequently. That is why it is important to develop a NR price forecasting model. Because there was a significant time lag between making output decisions and the actual output of the commodity in the market. The aim of this study is to determine the time series pattern for natural rubber price in Malaysia within 1995 until 2020 and to forecast the natural rubber price in Malaysia for 10 years ahead. The data used is from year 1995 until 2020 that were obtained from Malaysian Rubber Board (MRB). This study also used univariate forecasting like Naïve with Trend, Double Exponential Smoothing, Holt's Winter and Autoregressive Integrated Moving Average (ARIMA). Then, the measurement error is used to determine the best method to forecast the future data. The measurement error that used in this study are Mean Absolute Error, Mean Squared Error, Root Mean Square Error, Mean Absolute Percentage Error and The Theil Inequality Coefficient. Result: The natural rubber price in Malaysia showed a trend pattern. Then, ARIMA is used to determine the forecast of natural rubber price for next 10 years since it has the lowest measurement error. Conclusion: There are volatility in the price of natural rubber in Malaysia over the next 10 years.
\end{abstract}

Key words: natural rubber price, forecasting, measurement forecasting error

\section{Introduction}

Arias and Dijk (2019) stated that natural rubber is an important polymer in human society, where this study found that over 40,000 products have been produced for community use. Natural rubber is produced from latex, known as Havea Brasillensis. According to Khin et al (2008), Malaysia is the world's leading producer of rubber. The rubber industry is one of the backbones and has become one of the key sectors of Malaysia's economy. Moreover, the rubber industry is one of the components of the agricultural sector that contributes to Malaysia's national prosperity and gross domestic product (GDP). Figure 1 shows the trend between natural rubber SMR20 price and exchange rate (RM/USD). It reveals that they are having a negative relationship with each other. Most of the agricultural commodities including natural rubber are traded internationally in terms of USD. (Burger et al. (2002) found any fluctuation in the currency exchange rate would have an impact on the market. 
Figure1: Natural Rubber Prices (SMR20)

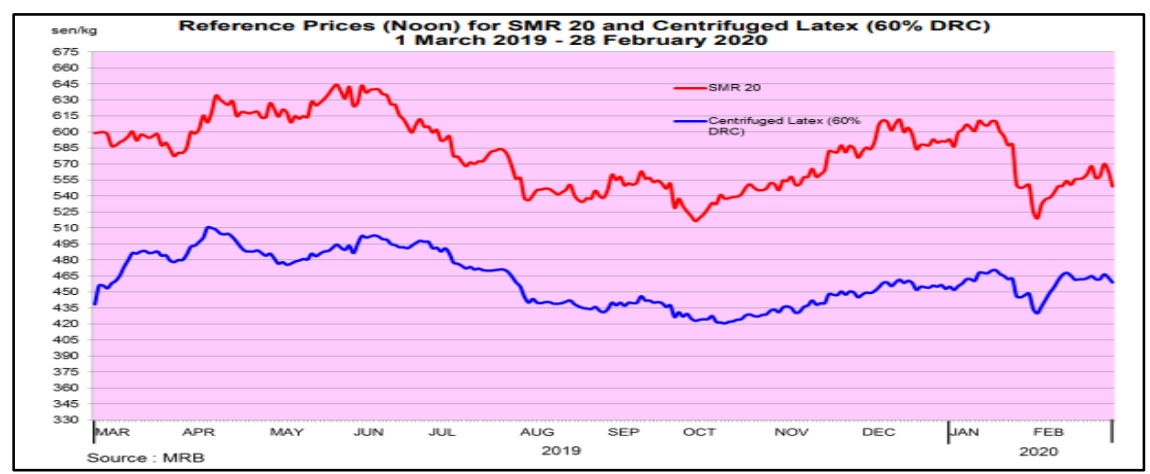

The Malaysia Rubber Board (MRB) says that since February 2016 the country's rubber price is the international market price and the drop in rubber prices was due to changing demand for global rubber. With the spread of the Covid-19, demand from major natural rubber consumer countries such as China is declining (Malaysia Rubber Board, 2020). This condition reflected the standard rubber price, which on 2 April 2020 recorded at the beginning of the year, the price was down to 24 percent which is RM4.50 per kg.

Raju (2016) also stated that synthetic rubber prices and crude oil prices influence NR prices, with the decline in oil prices and subsequent decline in synthetic rubber prices being some of the factors that have contributed to the volatility and instability in NR prices. This is because the NR exporting countries were affected by the economic slowdown, particularly currency depreciation, which contributed to the decline in NR prices in these countries.

Lastly, the price of Standard Malaysia Rubber 20 (SMR20) always varies from time to time. That is why it is importance to do a forecasting model on price of NR. The high accuracy in price forecasts were particularly important to facilitate the decision- makers to make efficient decision making (Ismail Z., Abu N. \& Sufahani S., 2016). In this study, there are two objectives need to achieve which are to determine the time series pattern for natural rubber price in Malaysia from 1995 until 2020 and to forecast natural rubber price in Malaysia by 2030.

\section{Literature Review}

\section{History of Rubber}

In the 19th century, British scientists brought the rubber tree to Malaysia from South America and it is now cultivated in many Asian countries (Fox and Castella, 2013; Nyaka Ngobisa et al., 2013). Malaysia was one of the major producers of natural rubber in the 1960s. So, many of the Chinese and Indians live in Malaysia are descendants of laborer's brought to work on the rubber plantations.

In addition, Malaysia as a developing country which similar to India, also concerns in the production of the rubber. Products from rubber is said to be saturated in our world. It is widely used in various fields. The two fundamental types of rubber are natural rubber and synthetic rubber. However, either type of the product could also produce various subordinate rubber materials with different degrees of hardness (Dontigney, 2014).

\section{Natural Rubber}

Natural rubber has first been identified in the Amazon (Oghenekome, 2004). Brazil was fantastic at making rubber that once made it prosperous. The seeds of rubber tree were then shipped to Britain and 
Asia's British colonies. In recent years Asia has been actively involved in processing natural rubber in the large fields of rubber. The process of development of natural rubber began with rubber trees reproduction. The harvesting of rubber can only be carried out after seven years of cultivation of rubber trees.

Nowadays, the supply of Natural Rubber (Latex) is commonly used for the manufacture of a vast range of living items such as gloves, mattresses, globes and swim caps. These products should be recycled in order to avoid contaminating environment (Swetha and Rani, 2014). Natural rubber latex serves as an elastic band in cold weather that helps prevent cracks from forming while preserving bitumen stiffness. Wen et al. (2017) said that natural rubber functions as a film that enhances shear resistance if the temperature rises, which in turn avoids bitumen flow.

\section{Forecasting Techniques in Natural Rubber Price}

Multiple forecasts for autoregressive-integrated moving-average (ARIMA) models can be useful in a variety of fields, including economics and business forecasting. Khin (2011) used a variety of forecasting models, like ARIMA, to forecast the short-term future price of natural rubber in Malaysia, where both ex-ante and ex-post forecasting is done. Next, Khin et al. (2008) also used Box-Jenkins's methods to match the historical prices of Standard Malaysian Rubber 20 in a time series model from January 1990 to December 2006 and it was concluded that the data fits a 9 ARIMA $(1,1,1)$ model, and the results showed that forecasting values are satisfactory.

Furthermore, short-term ex ante estimates of Malaysian crude palm oil prices were presented by Shamsudin and Fatimah (2000). The forecasts were derived using a multivariate autoregressive-moving average (MARMA) model, which incorporates the residuals' normal autoregressive integrated moving average (ARIMA) model into an econometric equation that was estimated before. In addition, Burger and Smit (2000) also investigated the natural rubber market's long-term and short-term trends. It included the economies of key players in the natural rubber market on both the demand and supply sides, as well as price fluctuations.

Jit Yang Lim (2002) also estimated short-term NR prices and the performance of 19 models based on three forecasting techniques and four information sets. Lastly, Md Zakir Hossain (2006) developed and used commodity price forecasts for policy purposes. It was to generate three types of forecasts, namely historical, ex-post, and ex-ante, for motor, mash, and mung prices in Bangladesh using the world-famous Box-Jenkins time series models.

\section{Methodology}

\section{Research Process}

Study design is a research or analysis method or approach used for collecting the necessary data in order to achieve the aims of the study (Mohamad Najib, 1999). In this study, the analysis starts with defining the research problem. Then, we need to determine the objectives to fulfil this study. Next, forecasting technique is used to summarize the output. Lastly, the result will be interpreted to summarize this study.

\section{Data Collection}

Data on the natural rubber price was gathered for this study. This involves a secondary data source. The monthly spot prices of SMR20 will be analyzed in this research. The data is drawn from The Malaysia Rubber Board (MRB). The monthly data consists of 312 observations from January 1995 to December 2020.

\section{Data Analysis}


In general, a time series is thought to be influenced by four major components that can be separated from the observed data (David W. Gerbing, 2016). These elements are Trend, Cyclical, Seasonal, and Irregular. In this study, we used univariate time series models, namely the Naïve with trend, Double Exponential Smoothing, Holt-Winter's model and Autoregressive integrated Moving Average (ARIMA). Naïve method is the simplest technique and very easy to used (Hyndman \& Athanasopoulos, 2016). The equation of simple naïve and naïve with trend model are:

$$
Y_{t+1}=Y_{t} \quad \text { and } \quad F_{t+1}=y_{t} \frac{y_{t}}{y_{t-1}}
$$

Holt's double exponential smoothing, also known as Holt's linear exponential smoothing, is a type of double exponential smoothing widely used by people. This technique not only smooth the trend and the slope directly by using different smoothing constant, but also provides more flexibility in selecting the rates at which trend and slopes are tracked (ANRPC, 2009). There are three equations incorporated in this technique.

$$
\begin{gathered}
L_{t}=\alpha Y_{t}+(1-\alpha)\left(L_{t-1}+T_{t-1}\right) \\
T_{t}=\beta\left(L_{t}-L_{t-1}\right)+(1-\beta) T_{t-1} \\
F_{t+k}=L_{t}+k T_{t}
\end{gathered}
$$

The triple exponential smoothing method used when there are trend and seasonality in the data series. The equation in this method is:

$$
\begin{array}{cc}
S_{t}=\alpha\left(y_{t}-S n_{t-L}\right)+(1-\alpha)\left(S_{t-1}+b_{t-1}\right), & 0<\alpha \leq 1,2 \leq t \leq n \\
b_{t}=\beta\left(S_{t}+S_{t-1}\right)+(1-\beta) b_{t-1}, & 0<\beta \leq 1,2 \leq t \leq n \\
S n_{t}=\gamma\left(y_{t}-S_{t}\right)+(1-\gamma) S n_{t-L}, & 0<\gamma \leq 1,2 \leq t \leq n
\end{array}
$$

The autoregressive integrated moving average is a combination of autoregressive (AR) and movingaverage (MA) models. The equation for this process is:

$$
Y_{t}=\theta_{1} Y_{t-1}+\tau_{t}
$$

After the analyze of the data, the forecasting measurement error was determined for each method. This is because the best fit of forecasting method of the data will be selected based on the measurement of forecast error that has the least error value. The accuracy that used are mean absolute error (MAE), mean squared error (MSE), root mean square error (RMSE), mean absolute percentage error (MAPE) and the Theil inequality coefficient (TIC). Lastly, the method that has been chosen will be forecast the natural rubber price for next 10 years.

\section{Results and Findings}

\section{Time Series Model}

Figure 3 shows the graph of time series pattern. The graph showed that the data has a trend pattern. From the graph, we can see that between the year of 1995 to 2000, the natural rubber price become decrease. This is because the production of natural rubber is low. M.L. Nur Hazirah, A. Shri Dewi \& A. Hussin (2016) state in early 1995s, the amount of rubber estate decreased to 1,048 estates. From 2000 to mid-2008, there appeared to be an uptrend in the price of natural rubber. In the fourth quarter of 2008, the price of SMR 20 plummeted owing to the global economic downturn, which resulted in lower demand for natural rubber.

In year 2012 the contribution of natural rubber exported was only 1.12 percent. Based on Byerlee (2014), the substantial increase in natural rubber prices was due to growing demand from China and other rapidly industrializing countries between 2001 and 2012, and prices fell between 2013 and 2016 as a result of 
holdover and excess supplies within Chinese markets. Lastly, between 2017 and 2019 we can see clearly the volatility of natural rubber price. This is because any change in environmental factors is additionally due to the assumption that fluctuations in the exchange rate market and the crude oil market are associated with fluctuations in the price (Sang et. al., 2012). Furthermore, in 2020 we can see the price is fell down due to the Covid-19 pandemic. This is because Covid-19 pandemic outbreak demand from major natural rubber consumer countries such as China, United States (US), Iran and countries in Europe.

Figure 3: Time Series Pattern

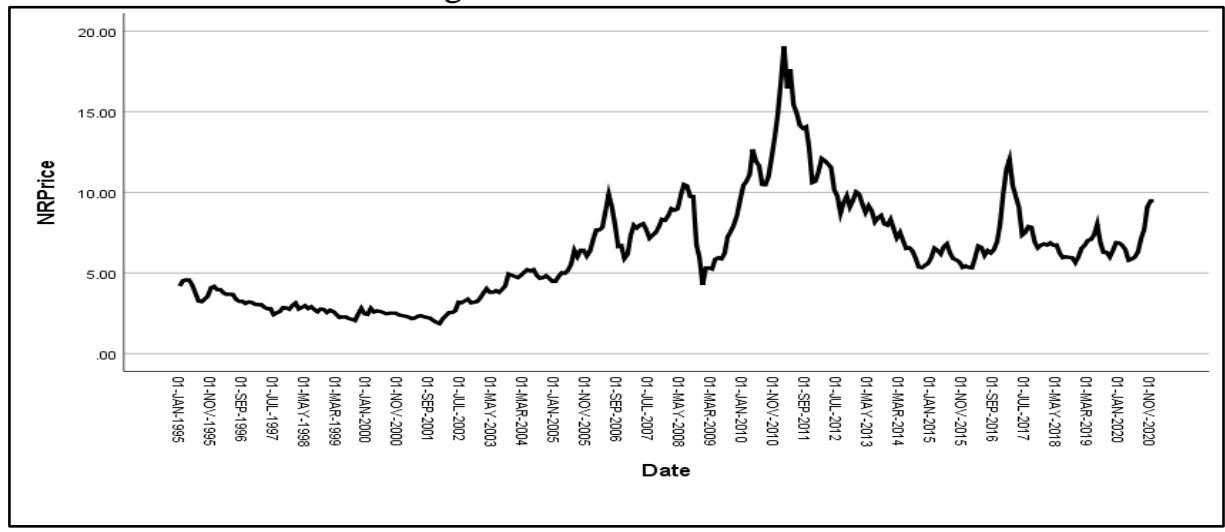

\section{Forecasting Methods}

\section{Naïve with Trend}

Table 1 shows the measuring of forecasting error. We can see the value of MAE is 0.457260 , MSE is 0.432471 , RMSE is 0.67625 , MAPE is 5.994378 and TIC value is 0.004648 . So, from the measure forecast error we can conclude that TIC value is the best value which is 0.004648 since it is the lowest value among others measure forecast error.

Table 1: Error measurement of natural rubber price using Naïve with Trend

\begin{tabular}{ccccc}
\hline MAE & MSE & RMSE & MAPE & TIC \\
\hline 0.457260 & 0.432471 & 0.67625 & 5.994378 & 0.004648 \\
\hline
\end{tabular}

\section{Double Exponential Smoothing}

The result for five type of error measurement shows at table 2 below. In the table 4.2 , the result is MAE (0.238214), MSE (0.114668), RMSE (0.338627), MAPE 3.077900) and TIC (0.02404). From this result, the measurement forecast error that has least value is TIC which is 0.02404 . So, Theil's U is the best forecast error measurement.

Table 2: Error measurement of natural rubber price using Double Exponential Smoothing Method

\begin{tabular}{ccccc}
\hline MAE & MSE & RMSE & MAPE & TIC \\
\hline 0.238214 & 0.114668 & 0.338627 & 3.077900 & 0.02404 \\
\hline
\end{tabular}

\section{Triple Exponential Smoothing (Holt's Method)}

Table 3 show the listed of five type of error measurement. According to table 4.3 below, the result each error measurement was 44.577700 (MAE), 2714.989940 (MSE), 52.105565 (RMSE), 589.206326 (MAPE) and 3.29667048 (TIC). So, from the measure forecast error we can conclude that TIC value is the best value which is 3.29667048 since it is the lowest value among others forecast error measurement. 
DOI: https://doi.org/10.47405/mjssh.v6i9.986

Table 3: Error measurement of natural rubber price using Triple Exponential Smoothing Method (Holt's Winter)

\begin{tabular}{ccccc}
\hline MAE & MSE & RMSE & MAPE & TIC \\
\hline 44.577700 & 2714.989940 & 52.105565 & 589.206326 & 3.29667048
\end{tabular}

\section{Autoregressive Integrated Moving Average Method (ARIMA)}

ARIMA method is a bit different from others method. This is because, the data must be stationary data before proceeding with analyze using the ARIMA method. From time series graph of price natural rubber in Figure 4 and Figure 5. It showed that the time series of price of natural rubber and time was non stationary data.

Figure 4: ACF Graph Before Transform Figure 5: PACF Graph Before Transform

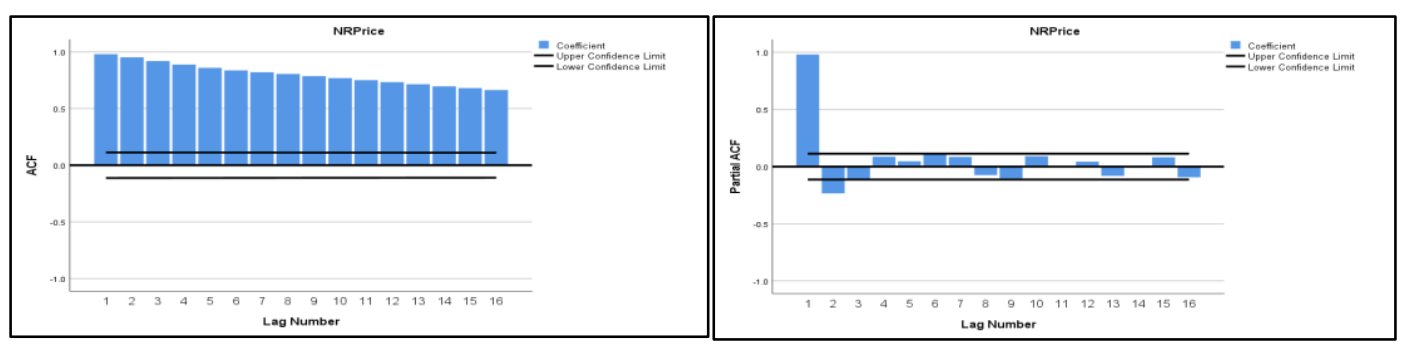

Figure 6: ACF Graph After Transform Figure 7: PACF Graph After Transform
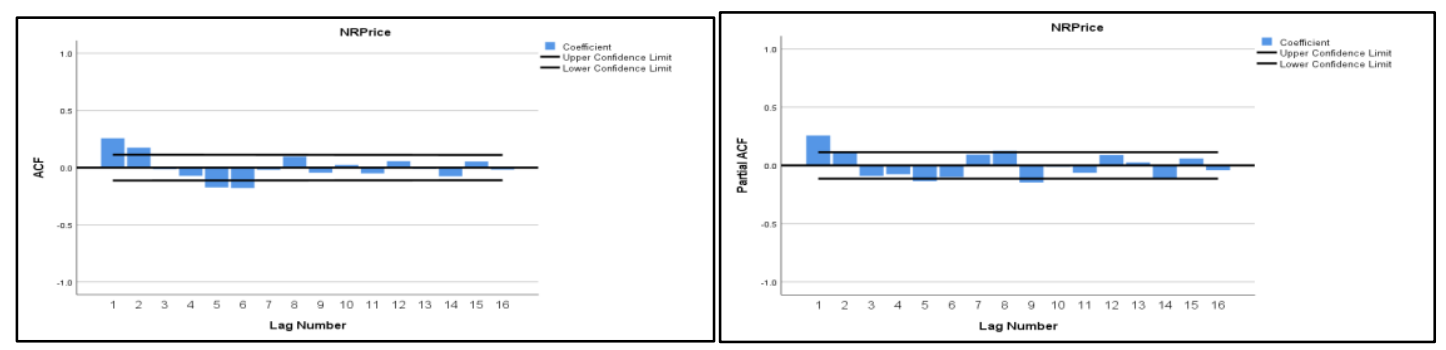

From Figure 6 and 7 above, we will be used the result to know the ARIMA (p, d, q) values. Figure 6 and 7 shows the differencing occur one time to make the data is stationary, so the value of $\mathrm{d}$ is 1 . In Figure 7, we can see there are two spikes on lag 1 and 2, so value of $q$ is 2 . Then there are also 2 spikes between lag 5 and lag 12 , so the value of $\mathrm{p}$ is 2 . As the result ARIMA $(2,1,2)$ will be analyze using SPSS.

Table 4: Model Statistic of natural rubber price using ARIMA $(2,1,2)$

\begin{tabular}{|c|c|c|c|c|c|c|c|c|}
\hline \multicolumn{9}{|c|}{ Model Statistics } \\
\hline \multirow[b]{2}{*}{ Model } & \multirow{2}{*}{$\begin{array}{c}\text { Number } \\
\text { of } \\
\text { Predictors }\end{array}$} & \multicolumn{3}{|c|}{ Model Fit statistics } & \multicolumn{3}{|c|}{ Ljung-Box Q (18) } & \multirow[b]{2}{*}{$\begin{array}{c}\text { Number of } \\
\text { Outliers }\end{array}$} \\
\hline & & $\begin{array}{l}\text { Stationary } \\
\text { R-squared }\end{array}$ & $\begin{array}{c}\mathrm{R}- \\
\text { squared }\end{array}$ & RMSE MAPE MAE & Statistics & $\mathrm{DF}$ & Sig. & \\
\hline price- & 0 & 0.150 & 0.566 & 2.15224 .3781 .555 & 1019.331 & 14 & .000 & 0 \\
\hline \multicolumn{9}{|c|}{ Model__ } \\
\hline 1 & & & & & & & & \\
\hline
\end{tabular}


DOI: https://doi.org/10.47405/mjssh.v6i9.986

Based on table 4 above, the result show that MAE is 1.4667, MSE is 1.4667, RMSE is 2.152 and MAPE is 24.378. In ARIMA, the best forecast error value is MSE which is 1.4667.

\section{Combination of All the Error using Selected Methods}

The error measurement result for each method using in this study already list in one table. The Table 5 shows that the error measurement from Naïve with Trend, Double Exponential Smoothing, Holt's Winter and ARIMA $(2,1,2)$.

Table 5: Combination of All the Error Measurement Using Selected Method

\begin{tabular}{cccccc}
\hline $\begin{array}{c}\text { Types of } \\
\text { Error/Methods }\end{array}$ & MAE & MSE & RMSE & MAPE & TIC \\
\hline Naïve with Trend & 0.457260091 & 0.432470984 & 0.657625261 & 5.994377719 & 0.046481 \\
$\begin{array}{c}\text { Double } \\
\text { Exponential } \\
\text { Smoothing }\end{array}$ & 0.238214472 & 0.11466803 & 0.338626682 & 3.077900059 & 0.024044 \\
$\begin{array}{c}\text { Holt's Method } \\
\text { Autoregressive } \\
\text { Integrated Moving } \\
\text { Average Method } \\
\text { (ARIMA) }\end{array}$ & 44.57770024 & 2714.98994 & 52.10556535 & 589.2063262 & 3.29667 \\
\hline
\end{tabular}

From the result in Table 5, Autoregressive Integrated Moving Average Method have the least error value compared to the other technique. The least error implies the best fit model. Thus, ARIMA was selected. The method selected will then use to forecast the value of natural rubber price.

\section{Forecasting for 10 Years later Using Autoregressive Integrated Moving Average Method (ARIMA)}

This study will be ARIMA to calculate the future forecasting values. The results of applying Autoregressive Integrated Moving Average Method on our dataset using SPSS are in Figure 8 and Figure 9. We can see that the price of natural rubber in Malaysia for the next 10 years has volatility which is upward and downward. Despite, it is a common situation in Natural Rubber Price Industries due to some factors that make the price increased and decreased. Furthermore, the price of natural rubber in 2021 continuedly increased. The price of SMR20 9.44 in January 2021 increased to SMR20 11.43 in December 2030.

Figure 9: Graph Of 10 Year Ahead of Natural Rubber Price in Malaysia

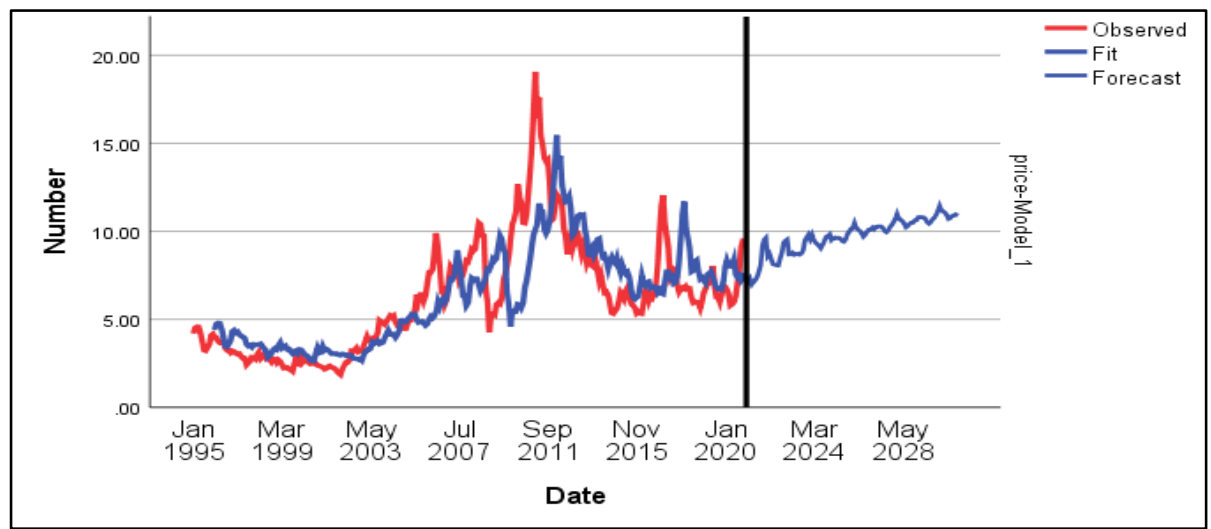



DOI: https://doi.org/10.47405/mjssh.v6i9.986

Figure 8: Future Forecast Value for 10 Years of Natural Rubber Price in Malaysia

\begin{tabular}{|c|c|c|c|c|c|c|c|c|c|}
\hline JEก| 21 & $7 \equiv \Xi$ & ل:пा -23 & B.eg & lan-25 & s.51 & $\int \equiv n \mid-27$ & 1012 & $1=\cap 1-20$ & Iases \\
\hline$F=1-21$ & 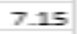 & $F=a-z B$ & a. 7 & Fel-DE & Ee: & $f=D-27$ & 1026 & $F=0-20$ & 10. \\
\hline$M E=-21$ & 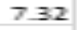 & Mar-zB & $\mathbb{B} .7$ & Mlar-25 & ges & $M a=-27$ & 10128 & $\mathrm{M}=-2$ & Iare \\
\hline$A p \|=21$ & E.90 & Apr -23 & B.eS & Har-DS & ge日 & $A D=I 7$ & 1018 & Apr-20 & 10181 \\
\hline $\mathrm{Mar}-\mathrm{Z1}$ & 712 & Nher -23 & $8 \pi 2$ & May-75 & GEA & $\mathrm{Ma} r-27$ & 1028 & Nay- 20 & $10 \Xi$ \\
\hline ปแกー 211 & 722 & Jun -23 & $\mathbb{B} \pi 2$ & Jurn-25 & 도도 & ปแกー 2 ? & $10 \geq 1$ & ป I & 1071 \\
\hline 」Ul-Z1 & 7.4 & \lrcorner $山-23$ & B.es & Jull-2S & Gas & لـ -27 & 10002 & 」งl- 20 & $10 \leq 1$ \\
\hline AME 21 & 771 & $A_{M}=-23$ & 873 & MuE-D & G.41 & AнE- 27 & 9日9) & AUE 20 & 1043 \\
\hline $5=p-21$ & Bor & $5=a-23$ & a 92 & $5=1-25$ & 5959 & $s=p-27$ & 1004 & $5=p-20$ & $10 \leq 1$ \\
\hline Det-21 & 915 & Ohet-23 & 9.45 & $a x-25$ & 584 & Dict $=27$ & 1020 & Des- 20 & 10es \\
\hline Non-21 & 952 & Non-23 & 9 .ent & Now-Zs & Sas? & Now-27 & $10 \equiv 5$ & Wow -20 & 1ane \\
\hline$D=c-21$ & G.63 & Dect- -23 & $9 . \mathrm{Bz}$ & Dec-1s & $10 \pm 4$ & $D=c-27$ & $10 \equiv 2$ & $D=0-20$ & 1000 \\
\hline$d \equiv n-z Z$ & B.s & J:an-24 & 9.55 & Ian-21E & 200 & $d \equiv n-28$ & IDUe日 & IE=า1- 30 & 1114 \\
\hline$F=b-22$ & B.73 & $F=1-24$ & 9.8 & $F=b-2 E$ & \pm 047 & $F \equiv D-2 \theta$ & 1050 & $F=b-30$ & 1144 \\
\hline$M \equiv=22$ & 842 & MI: $=1-2$ & 9.49 & War-2E & 10 :a & $M=-2 B$ & 1071 & Me $=30$ & 1118 \\
\hline Apir 22 & 813 & Apr-24 & $9 \pm 5$ & 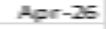 & 201 & $A p=28$ & 10ues & Apr- 30 & 1115 \\
\hline Mar-22 & E1 & Nher -20 & 928 & Mar-2e & 2000 & $\mathrm{Mer}_{\mathrm{r}}-\mathrm{Zs}$ & $10 \equiv 8$ & Nay-30 & 1100 \\
\hline Jun- $Z Z$ & B.07 & IUा $-2 \mu$ & 9.19 & JuIT-ZE & 99.1 & لแח- $2 \theta$ & 1040 & 」แnー & 1004 \\
\hline $\int u l-2 z$ & B.0@ & Iull -2 & 9.04 & Jull-2E & 9.7 & لـ $-2 B$ & 1029 & لـ & 1071 \\
\hline AHE-22 & 8.44 & $A \cup B-24$ & 923 & Mug-2E & Sta: & AME-28 & 1029 & AUE-30 & 1074 \\
\hline $5=0-22$ & Bne & $\Sigma=0-24$ & 9.40 & $\sec -26$ & Ese & $5 \equiv p-2 a$ & 10.43 & $5=0-30$ & $10 \equiv \pi$ \\
\hline Detzz & $9 \pm 4$ & Dett-2u & 9 . & Des:-2As & Mangs & bet-2a & $10 \leq$ & Den- 30 & 10192 \\
\hline Wian-22 & 9.47 & Now-2u & 9.73 & How-3E & 10109 & Nion-28 & 10.49 & Non-30 & 1091 \\
\hline$D=0-22$ & $95=$ & $D=c-24$ & 9 표르 & Dec- $2 E$ & 1021 & $D=c-1 \theta$ & 10 en & $D=0-30$ & 1100 \\
\hline
\end{tabular}

\section{Conclusion}

First objective need to be achieved is to determine the pattern of natural rubber price. As a result, the plot shows a trend pattern in the data series. This trend pattern represents the long-run growth or decline over time. Next, the second purpose of this study is to forecast the future natural rubber price in Malaysia 10 years ahead. There are several types of forecasting methods been used. As for this study, we used univariate time series models, namely the Naïve with trend, Double Exponential Smoothing, HoltWinter's model and Autoregressive integrated Moving Average (ARIMA). After the analyze of the data, the forecasting measurement error was determined for each method. This is because the best fit of forecasting method of the data will be selected.

The measurement values of forecasting error for Naïve with Trend are MAE is 0.457260 , MSE is 0.432471, RMSE is 0.67625, MAPE is 5.994378 and TIC value is 0.004648. Next, the result for Double Exponential Smoothing errors is MAE is 0.238214 , MSE is 0.114668 , RMSE is 0.338627 , MAPE is 3.077900 and TIC is 0.02404 . Then, the result each error measurement is 44.577700 (MAE), 2714.989940 (MSE), 52.105565 (RMSE), 589.206326 (MAPE) and 3.29667048 (TIC) for Triple Exponential Smoothing (Holt's Winter). Lastly, the result for Autoregressive Integrated Moving Average Method (ARIMA) is 1.4667 for MAE, 1.4667 for MSE, 2.152 for RMSE and 24.378 for MAPE.

Lastly, the method which has the least measurement error has been choose to forecast the natural rubber price in Malaysia for 10 years ahead. So, in terms of accuracy the Autoregressive Integrated Moving Average Method have the lowest error when compared to other techniques. As a result, there are volatility in the price of natural rubber in Malaysia over the next 10 years. Despite, this is a common situation in the NR Price Industries due to a variety of factors that can cause the price to fluctuate. Furthermore, the price of natural rubber increased steadily from 2021 to 2030, rising from SMR20 9.44 in January 2021 to SMR20 11.43 in December 2030.

\section{References}

Arias M \& van Dijk P (2019) What Is Natural Rubber and Why Are We Searching for New Sources? Front. Young Minds, 7:100. doi: 10.3389/frym.2019.00100.

Burger, K., \& H. P. Smit. (2000). Long-Term and Short-Term Analysis of the Natural Rubber Market. Department of Econometrics, Economic and Social Institute, Faculty of Economics and Business Administration, Vrije University, De Boolean 1105, 1081 HV Amsterdam, The Netherlands. 
Burger, K., Smit H. P. \& Vogalvang, B. (2002). Exchange rates and natural rubber prices, the effect of the Asian crisis. 10th EAAE Congress: Exploring Diversity in the European agri food system. http://ageconsearch.umn.edu/bitstream/24958/1/cp02bu31.pdf

Byerlee, D. (2014). The Fall and Rise Again of Plantations in Tropical Asia: History Repeated? Land. 3. 574-597. 10.3390/land3030574.

David W. G. (2016). Time Series Components. The School of Business, Portland State University. Crude Palm Oil Prices, http://www.econ.upm.edu.my/-fatimah/pipoc-.html.

Dontigney, E. (2014). The Manufacturing Process of Rubber. Retrieved from http://seaconcorp.com/post$\underline{21}$.

Fox J \& Castella J-C (2013) Expansion of rubber (Hevea brasiliensis) in Mainland Southeast Asia: what are the pros-pects for smallholders? The Journal of Peasant Studies, 40(1):155-170.

Ismail Z, Abu N \& Sufahani S (2016). New Product Forecasting with Limited or No Data AIP Conference Proceedings 1782050009.

Jamil Wee, Siti Murni Wee \& Singaravelloo, Kuppusamy. (2018). Income targets and poverty of rubber smallholders in four states of Malaysia. Planning Malaysia Journal, 16. 10.21837/pmjournal. v16.i5.440.

Jit Yang Lim. (2002). An Evaluation of Alternative Forecasting Models for Natural Rubber Prices, Unpublished doctoral dissertation, Curtin University of Technology, Australia

Khin A. A. (2011). Econometrics forecasting models for short term natural rubber prices. Saarbrcken, Germany: Lambert Academic Publishing.

Khin, A. A., Chong, E. C., Shamsudin, M. N., \& Mohamed, Z. A. (2008). Natural rubber price forecasting in the world market. Proceeding of the Agriculture Sustainability through Participative Global Extension AGREX08, Putrajaya, Malaysia. https://www.researchgate.net/publication/282783451_NATURAL_RUBBER_PRICE_FORECA STING_IN_THE_WORLD_MARKET

M.L. Nur Hazirah, A. Shri Dewi \& A. Hussin (2016). An Econometric Analysis of Natural Rubber Market in Malaysia: International Journal of Environmental \& Agriculture Research (IJOEAR), 2.

Mad Nasir Shamsudin \& Fatimah Mohd Arshad. (2000). Short Term Forecasting of Malaysian

Malaysian Rubber Board (2020). A monthly publication of the Malaysian Rubber Board.

Md Zakir Hossain. (2006). ARIMA model and forecasting with three types of pulse prices in Bangladesh.

Mohamad Najib Abdul Ghafar (1999). Penyelidikan Pendidikan. Skudai: Penerbitan Universiti Teknologi Malaysia.

Nyaka Ngobisa AIC, Zainal Abidin MA, Wong MY. et al. (2013) Neofusicoccum ribis associated with leaf blight on rubber (Hevea brasiliensis) in Peninsular Malaysia. Plant PathologyJournal, 29(1): $10-16$.

Oghenekome, U.O. Natural rubber, Hevea brasiliensis (Willd. ex A. Juss.) Müll. Arg, germplasm collection in the Amazon Basin, Brazil: A retrospective. Econ Bot 58, 544-555. https://doi.org/10.1663/0013-0001(2004)058.

Raju, K. V. (2016). Instability in natural rubber prices in India: An empirical analysis. Journal of Economics and Finance, 7(2), 24-28.

Sang, W. C., Sriboonchitta, S., Rahman, S., Huang, W. T., \& Wiboonpongse, A. (2012). Modeling volatility and interdependencies of Thai rubber spot price return with climatic factors, exchange rate and crude oil markets.

Swetha, D. V. and Rani, K. D. (2014). Effect of Natural Rubber on the Properties of Bitumen and Bituminious Mixes. International Journal of Civil Engineering and Technology, 5(10), 9-21.

Wen, Y., Wang, Y., Zhao, K. \& Sumalee, A. 2017. The Use of Natural Rubber Latex as a Renewable and Sustainable Modifier of Asphalt Binder. International Journal of Pavement Engineering, 18(6), 547-559.

Hyndman, R.J., \& Athanasopoulos, G. (2016). Forecasting: Principles and practice, an online text book. Retrieved from https://www.otexts.org/fpp/2/3 Accessed on 12.11.2016.

ANRPC (2009). Trends of natural rubber price. Association of Natural Rubber Producing Countries, Malaysia. http://www.anrpc.org/. 